\title{
Could the Musk Compound Tonalide Affect Physiological Functions and Act as an Endocrine Disruptor in Rainbow Trout?
}

\author{
Nikola HODKOVICOVA ${ }^{1}$, Vladimira ENEVOVA ${ }^{2}$, Jana CAHOVA ${ }^{2}$, Jana BLAHOVA ${ }^{2}$, \\ Zuzana SIROKA $^{2}$, Lucie PLHALOVA ${ }^{2}$, Veronika DOUBKOVA ${ }^{2}$, Petr MARSALEK ${ }^{2}$, Ales \\ FRANC $^{3}$, Emma FIORINO ${ }^{4}$, Caterina FAGGIO ${ }^{4}$, Frantisek TICHY ${ }^{5}$, Martin FALDYNA ${ }^{1}$, \\ Zdenka SVOBODOVA ${ }^{2}$
}

${ }^{1}$ Department of Infectious Diseases and Preventive Medicine, Veterinary Research Institute, Brno, Czech Republic, ${ }^{2}$ Department of Animal Protection and Welfare \& Veterinary Public Health, Faculty of Veterinary Hygiene and Ecology, University of Veterinary and Pharmaceutical Sciences Brno, Czech Republic, ${ }^{3}$ Department of Pharmaceutics, Faculty of Pharmacy, Masaryk University, Brno, Czech Republic, ${ }^{4}$ Department of Chemical, Biological, Pharmaceutical and Environmental Sciences, University of Messina, Italy, ${ }^{5}$ Department of Anatomy, Histology and Embryology, Faculty of Veterinary Medicine, University of Veterinary and Pharmaceutical Sciences Brno, Czech Republic

Received October 8, 2020

Accepted October 24, 2020

\section{Summary}

In the present study, the effect of polycyclic musk compound tonalide (AHTN) in two concentrations was studied in male rainbow trout (Oncorhynchus mykiss, Walbaum 1792). A feeding trial was conducted with AHTN incorporated into feed granules. One concentration was environmentally relevant $(854 \mu \mathrm{g} / \mathrm{kg})$; the second one was $10 \times$ higher $(8699 \mu \mathrm{g} / \mathrm{kg})$. The fish were fed twice a day with the amount of feed at $1 \%$ of their body weight. After an acclimatization period, the experimental phase in duration of six weeks followed. At the end of the experiment, fish were sampled and the biometrical data were recorded. Subsequently, hematological and biochemical tests, histopathological examination, analysis of oxidative stress markers and evaluation of endocrine disruption using plasma vitellogenin were performed. In conclusion, an increase of hematocrit for both AHTN concentrations was found, but no significant changes were observed in biochemical profile. Moreover, AHTN caused lipid peroxidation in caudal kidney tissue, which was confirmed by histopathological images. The long-lasting AHTN exposure could thus be harmful for maintaining homeostasis in the rainbow trout organism. However, the vitellogenin concentration seemed not to be affected by AHTN.

\section{Key words}

Hematology • Biochemistry • Histology • Lipid peroxidation • Oncorhynchus mykiss

\section{Corresponding author}

N. Hodkovicova, Veterinary Research Institute, Hudcova 296/70, Brno, 621 00, Czech Republic. E-mail: hodkovicova@vri.cz

\section{Introduction}

The issue of water pollution caused by many different substances raises questions about their impact on the non-target aquatic organisms (Carlsson et al. 2013, Freitas et al. 2019, Sehonova et al. 2019). The musk compounds are widely used in various industries as a fragrance carrier - in perfumes, personal care products, washing powders, household detergents and sprays, candles, etc. (Nakata et al. 2015). They have been reported to have a potential to adversely affect non-target organisms, such as fish (Yamauchi et al. 2008), amphibians (Carlsson and Norrgren 2014, Pablos et al. 2015) and other aquatic organisms as summarized by Tumova et al. (2019). Both estrogenic and anti-estrogenic effects of musk have been described (Schreurs et al.

PHYSIOLOGICAL RESEARCH • ISSN 1802-9973 (online) 
2004, Luckenbach and Epel 2005, Simmons et al. 2010) as well as genotoxicity (Parolini et al. 2015), neurotoxicity (Heberer 2002), photosensitive effects (Fang et al. 2017), the potential to cause oxidative stress (Blahova et al. 2018) or a change in gene expression (Shi et al. 2013). Due to their reported bio-cumulative effects and long-term environmental persistence caused by lipophilicity, many of them were forbidden or their usage was limited (Rimkus 1999, European Commission 2009).

In industrial sector, synthetic musk compounds are replacing the natural ones ( $\mathrm{Li}$ et al. 2020). One of the main musk groups used are polycyclic musk compounds (PCMs), while tonalide (AHTN) and galaxolide (HHCB) are most abundant (Vallecillos et al. 2015). Their ability to enter surface water and sediment was documented in many studies (Rimkus 1999, Wong et al. 2019, Zhang et al. 2020) and the waste water treatment plant's (WWTP) effluent was detected as the main environmental source of PCMs (Ramierz et al. 2009, Homem et al. 2015). At WWTP, the purification of the musk compounds is less than $100 \%$ effective and depends on the applied technology. For example, the cleaning process for AHTN was reported not to be higher than $84 \%$ (Ren et al. 2013) or $89 \%$ (Wombacher and Hornbuckle 2009). Based on the study by Peck and Hornbuckle (2004), AHTN is adsorbed to sludge during the WWTP process. The AHTN concentration in WWTP influent was found to range between 49.9 and $64.6 \mu \mathrm{g} / \mathrm{l}$ (Chen et al. 2007, Vallecillos et al. 2015), while in the sludge the concentration was up to $169.3 \mathrm{mg} / \mathrm{kg}$ (Zeng et al. 2005).

The aim of the present study was to assess whether oral exposure to AHTN could affect hematological and biochemical indices in rainbow trout. Moreover, its effects on oxidative stress were evaluated, as well as the effects on vitellogenin (VTG) concentrations in male fish plasma due to its possible xenoestrogenic potential. The impact on selected organs was evaluated by histopathological analysis. The AHTN concentrations tested in our experiment were selected according to the concentrations detected in surface water as discussed above and summarized, for example, by Blahova et al. (2008) and Tumova et al. (2019). As well, the maximum concentrations detected in wild fish tissues were taken into consideration, while they were determined up to $52.1 \mu \mathrm{g} / \mathrm{kg}$ and $349 \mu \mathrm{g} / \mathrm{kg}$ in common carp's (Cyprinus carpio, Linnaeus 1758) muscle and liver tissue, respectively; or even up to $3700 \mu \mathrm{g} / \mathrm{kg}$ lipid weight in sea trout's (Salmo trutta, Linnaeus 1758) muscle (Fromme et al. 2001, Kannan et al. 2005, Lange et al. 2015, Yao et al. 2018). The bioconcentration and bioaccumulation factors in wild fish species were considered for these concentrations to be environmentally relevant and also for testing the dose-dependent effects.

\section{Methods}

\section{Ethical statement}

After approval by the institutional ethical committee, the experiment was carried out in accordance with institutional guidelines and national legislation (Act No. 246/1992 Coll., on the Protection of Animals against Cruelty, as amended).

\section{Experimental design \& fish condition}

The trial was conducted at the Dpt. of Ecology $\&$ Diseases of Zooanimals, Game, Fish and Bees at the University of Veterinary and Pharmaceutical Sciences Brno, Czechia. A total of 60 male juveniles of rainbow trout from Skalni Mlyn hatchery were obtained (total length $\quad 32.2 \pm 2.2 \mathrm{~cm}$, weight $516.8 \pm 102.9 \mathrm{~g}$ ) and acclimated to the laboratory conditions for two weeks. The aquaria $(n=6)$ were connected to a recirculation system, while the condition of water was monitored every $24 \mathrm{~h}$ and was as follows: temperature $14.5-15.6{ }^{\circ} \mathrm{C}$, dissolved oxygen $>70 \%, \mathrm{pH} 7.9-8.3$, total ammonia $<0.03 \mathrm{mg} / \mathrm{l}$, chlorides $26.71 \mathrm{mg} / \mathrm{l}$, ammonia $0.23 \mathrm{mg} / \mathrm{l}$, nitrites $0.12 \mathrm{mg} / 1$, nitrates $45.44 \mathrm{mg} / 1$. Every aquarium was individually aerated. Fish were held at a $12 \mathrm{~h} / 12 \mathrm{~h}$ light to dark photoperiod during both the acclimatization and experimental phase. The probe Oxi 340i and $\mathrm{pH} 340 \mathrm{i}$ digital sampling systems were applied for measurement of $\mathrm{O}_{2}$ and $\mathrm{pH}$ in water (WTWGmbH, Germany). The spectrophotometric methods according to the Animal and Plant Health Agency (APHA 2017) methodology was used for determination of ammonia and nitrites in water samples (method No. 4500- $\mathrm{NH}_{3}, 4500-\mathrm{NO}_{2}$ ).

During the acclimatization period, fish were fed with commercial pellets EFICO Enviro 920 Advance $4.5 \mathrm{~mm}$ (Biomar, Denmark) twice a day with the amount of feed at $1 \%$ of their body weight. The composition of feeding pellets was as follows: $41-44 \%$ crude protein, $28-31 \%$ crude lipid, $13-16 \%$ carbohydrates, 0.7-2.2\% crude fiber, $4-7 \%$ ash, $0.9 \%$ total phosphorus. During the experimental phase, the same amount of feed was given to the fish, but with addition of AHTN. Every 14 days of the experimental phase, the fish were re-weighed and the amount of feed per day was recalculated. 
At the beginning of the experimental phase, the fish were randomly divided into three groups - control, AHTN1 and AHTN2 (n=20/per group); each group was divided and placed into two aquaria. The AHTN was tested in two concentrations which were incorporated into fish feed using a specific methodology described in detail by Modra et al. (2020). The first tested concentration was environmentally-relevant: $854 \mu \mathrm{g} / \mathrm{kg}$, thereafter designated as AHTN1. The second concentration, thereafter labelled as AHTN2, was ten times higher: $8699 \mu \mathrm{g} / \mathrm{kg}$. The feed for the control group was prepared in the same way, but without the use of AHTN. After six weeks of the experimental phase, all fish were sampled.

The monitored biometrical data were as follows: total and standard length $(\mathrm{cm})$, wet weight $(\mathrm{g})$ and weight of liver and gonads (g). For the measurement, a digital balance with an accuracy of up to $0.01 \mathrm{~g}$ was used. The wet weight and standard length were used for setting the Fulton's condition factor (CF) according to formula: $\mathrm{CF}=\left(\right.$ wet weight $[\mathrm{g}] /$ standard length $\left.[\mathrm{cm}]^{\wedge} 3\right) \times 100$ (Froese 2006). The hepatosomatic index (HSI) and gonadosomatic index (GSI) were calculated as: HSI (GSI) $=($ weight of tissue $[\mathrm{g}] /$ fish wet weight $[\mathrm{g}]$ ) $\times 100$ (Mazlan and Rohaya 2008).

\section{Determination of AHTN in the feed}

The measurement of AHTN was performed by gas chromatography coupled with ion trap tandem mass spectrometry (GC/MS/MS). A $5 \mathrm{~g}$ representative portion of fish feed granules was homogenized and extracted into cyclohexane $(10 \mathrm{ml})$. The extract was filtered through a $0.7 \mu \mathrm{m}$ glass filter (Millipore, USA) and used for GC/MS/MS analysis. The separation, identification, and quantification of AHTN were carried out using a Varian 450-GC gas chromatograph with a Varian 220-MS ion trap mass spectrometer equipped with electron ionization and VF-5ms $(30 \mathrm{~m} \times 0.25 \mathrm{~mm})$ column (Varian, Inc., USA). A $1 \mu \mathrm{l}$ aliquot of sample extract was injected in a split mode. The injector temperature was $250{ }^{\circ} \mathrm{C}$. The initial oven temperature was set at $50^{\circ} \mathrm{C}$ for $1 \mathrm{~min}$, increased at a rate of $35^{\circ} \mathrm{C} / \mathrm{min}$ to $280{ }^{\circ} \mathrm{C}$, held for $1 \mathrm{~min}$, increased at a rate of $20{ }^{\circ} \mathrm{C} / \mathrm{min}$ to $300{ }^{\circ} \mathrm{C}$ and held for $5 \mathrm{~min}$. The total run time was $14.57 \mathrm{~min}$. The ion trap mass spectrometer was operated in MS/MS mode. The most abundant ion $(\mathrm{m} / \mathrm{z}=243)$ was selected as a parent ion and ion $\mathrm{m} / \mathrm{z}=187$ was selected as a product ion. A standard of AHTN was purchased from Sigma-Aldrich (USA). Cyclohexane was GC/MS-grade purity (Chromservis, Czech Republic). For our
QA/QC program, the instrument was calibrated daily with multi-level calibration curves. Procedural blank and solvent blank were analysed for every set of 10 samples. The spiked recovery was $103 \%$. The reported concentrations after corrections are based on the recovery. The coefficient of variation for between-series was $6.1 \%$. The limit of detection was determined as $3: 1$ signal versus noise value and was $0.8 \mu \mathrm{g} / \mathrm{kg}$.

\section{Hematological analysis}

The blood was taken from each fish from the caudal vein using an aspiration syringe and was stabilized with sodium heparin (50 IU per $1 \mathrm{ml}$ of blood). After that, the fish were immediately stunned with a blow in the head, killed by spinal transection and submitted to autopsy. Each fish was weighed and measured, while the weight of the organs was also recorded. The whole blood was used for the red blood cell (RBC) and white blood cell (WBC) count determination with the use of the Burker hemocytometer to which the heparinized blood diluted with Natt-Herrick solution at a 1:200 ratio was applied. For the hematocrit (PCV) determination, the microhematocrit method with centrifugation of blood in capillary tubes was employed. The photometric cyanohemoglobin method at $540 \mathrm{~nm}$ was applied for the determination of hemoglobin concentration ( $\mathrm{Hb})$. Additionally, the mean erythrocyte hemoglobin (MCH), mean erythrocyte volume (MCV) and mean corpuscular hemoglobin concentration (MCHC) were calculated with using the $\mathrm{PCV}, \mathrm{Hb}$ and $\mathrm{RBC}$ data. All hematological analyses were performed based on the methodology by Svobodova et al. (2012).

\section{Biochemical analysis}

One half of each fish blood sample was centrifuged $\left(800 \times \mathrm{g}, 4^{\circ} \mathrm{C}, 10 \mathrm{~min}\right)$. In the obtained plasma, albumin (ALB), ammonia $\left(\mathrm{NH}_{3}\right)$, total protein (TP), glucose (GLU), triglycerides (TG), cholesterol (CHOL), lactate (LACT), calcium (Ca), phosphorus (PHOS), alkaline phosphatase (ALP), alanine aminotransferase (ALT), aspartate aminotransferase (AST) and lactate dehydrogenase (LDH) were evaluated. Biochemical parameters were determined using the commercial kit (BioVendor PCL, Czech Republic) and biochemical analyser Konelab 20i (Thermo Fisher Scientific, Czech Republic) following the manufacturer's instructions.

\section{VTG analysis}

The VTG concentration was detected in plasma 
samples using a commercial ELISA kit (Biosense Laboratories, Norway) following the manufacturer's instructions. The samples were taken from all fish $(n=60$, $20 \mathrm{pcs} /$ group), while males in the control group without exposure to AHTN served as a negative control.

\section{Oxidative stress analysis}

For oxidative stress evaluation, the activity of ceruloplasmin (CP) and ferric reducing ability of plasma (FRAP) were determined in plasma samples. The CP was determined spectrophotometrically using a Varioskan Flash Spectral Scanning Multimode Reader (Thermo Scientific Inc., USA) according to Ceron and MartinezSubiela (2004) methodology. The results are expressed as an amount of absorbance increase per minute $\times 10000$. The FRAP was analysed according the Benzie and Strain method (1996) with the use of a biochemical analyser Konelab 20 i.

The analysis of oxidative stress enzymes was performed in organs, specifically in liver, caudal kidney, gill and gonad tissue. The monitored parameters were glutathione reductase (GR), glutathione peroxidase (GPx), glutathione- $S$-transferase (GST) and thiobarbituric acid-substances (TBARS). The organs were individually homogenized and the homogenates were then divided into two parts. The first part was used for TBARS determination and the second part was centrifuged $\left(11000 \times \mathrm{g}, 4^{\circ} \mathrm{C}\right.$ for $20 \mathrm{~min}$ ) and the obtained supernatant was submitted to GR, GPx and GST analysis. The catalytic activities were determined spectrophotometrically with use of a Varioskan Flash Spectral Scanning Multimode Reader (Thermo Fisher Scientific Inc., USA). The GR activity was measured by determination of nicotinamide adenine dinucleotide phosphate (NADPH) oxidation at $340 \mathrm{~nm}$ according to the method of Carlberg and Mannervik (1975). The GPx activity determination was based on the NADPH oxidation rate and the reaction with GR at $340 \mathrm{~nm}$ (Flohe and Gunzler 1984). Both GR and GPx were expressed as nmol of NADPH consumption per min per mg of protein. The GST activity was detected using the Habig et al. (1974) methodology based on conjugation of 1-chloro-2,4dinitrobenzene with reduced glutathione at $340 \mathrm{~nm}$ and was expressed as nmol of the formed product per min per mg of protein. The Bicinchoninic Acid Protein Essay Kit (Sigma-Aldrich, USA) was employed for establishing of protein concentration with the use of bovine serum ALB as a standard (Smith et al. 1985). The levels of TBARS were determined by malondialdehyde measurement at
$535 \mathrm{~nm}$ (Lushchak et al. 2005) and were expressed as TBARS in nmol per gram of tissue. The TBARS concentrations were not determined in gonads due to a lack of tissue.

\section{Histopathological analysis}

The tissue of liver, cranial and caudal kidney, gill (upper limb of arch), spleen, gonads and skin (above the ventral fin) was dissected from each fish and submitted to histological analysis. Samples were fixed in buffered $10 \%$ neutral formalin, thereafter dehydrated and embedded in paraffin wax. Samples were sliced at a thickness of $4 \mu \mathrm{m}$ using the microtome tool. All samples were stained with hematoxylin-eosin dye and examined with light microscope.

\section{Statistical analysis}

The statistical software Unistat for Excel 6.5 (Unistat Ltd., UK) was employed for performing of the statistical analysis. Firstly, all data were tested for normality distribution using the Shapiro-Wilk test. In case of normality achievement, the analysis of variance and Tukey-HSD test were employed; while the KruskalWallis nonparametric test was applied for data with nonnormal distribution. The control, AHTN1 and AHTN2 groups were compared and data were considered as statistically significant when $\mathrm{p}<0.05(*)$ and $\mathrm{p}<0.01(* *)$. Data are expressed as mean \pm standard deviation (SD).

\section{Results}

\section{Mortality, behaviour and health status}

No mortality of fish was observed and the fish behaviour was not changed during any part of the experiment. Fish subjected to the trial were without bacterial, viral or parasitic infection at the beginning and at the end of the experiment. No significant changes were found in biometric indices thus these data are not presented.

\section{Hematological profile}

The only observable changes of hematological profile were found for PCV where a significant increase was detected for both concentrations of AHTN. The PCV increase in both concentrations was significantly different from the control group. However, the AHTN1 and AHTN2 groups did not differ between each other. Consequently, the changes in $\mathrm{PCV}$ parameter caused changes in MCV and MCHC levels, specifically the 
MCV increased after exposure to AHTN and, in contrast, the $\mathrm{MCHC}$ decreased. The $\mathrm{MCH}$ levels were also significantly different; a decrease in both AHTN concentrations was observed when compared to the control group. The other hematological parameters were not changed. An overview of hematological analysis after the induction of changes with AHTN is given in Table 1.

Table 1. Hematological and biochemical indices after oral exposure to two different concentrations of tonalide (AHTN): AHTN1 $(854 \mu \mathrm{g} / \mathrm{kg})$ and AHTN2 $(8699 \mu \mathrm{g} / \mathrm{kg})$.

\begin{tabular}{|c|c|c|c|}
\hline Parameter [unit] & Control & AHTN1 & AHTN2 \\
\hline \multicolumn{4}{|c|}{ Hematological indices } \\
\hline$R B C[T / l]$ & $1.37 \pm 0.06^{\mathrm{a}}$ & $1.54 \pm 0.05^{\mathrm{a}}$ & $1.46 \pm 0.06^{\mathrm{a}}$ \\
\hline $\mathrm{Hb}[\mathrm{g} / \mathrm{l}]$ & $83.87 \pm 3.08^{\mathrm{a}}$ & $80.72 \pm 1.73^{\mathrm{a}}$ & $78.21 \pm 2.25^{\mathrm{a}}$ \\
\hline$P C V[l / l]$ & $0.38 \pm 0.03^{\mathbf{b}}$ & $0.45 \pm 0.02^{\mathrm{a}}$ & $0.44 \pm 0.02^{\mathbf{a}, \mathbf{b}}$ \\
\hline$M C V[f l]$ & $262.07 \pm 11.75^{b}$ & $295.90 \pm 11.44^{\mathbf{a , b}}$ & $307.18 \pm 11.44^{\mathrm{a}}$ \\
\hline $\mathrm{MCH}[\mathrm{pg}]$ & $60.97 \pm 2.72^{\mathrm{a}}$ & $52.92 \pm 1.98^{\mathbf{b}}$ & $54.45 \pm 1.87^{\mathbf{a}, \mathbf{b}}$ \\
\hline$M C H C[g / l]$ & $0.24 \pm 0.03^{\mathrm{a}}$ & $0.18 \pm 0.01^{\mathbf{b}}$ & $0.18 \pm 0.01^{\mathbf{a}, \mathbf{b}}$ \\
\hline$W B C[G / l]$ & $18.03 \pm 1.43^{\mathrm{a}}$ & $19.54 \pm 2.17^{\mathrm{a}}$ & $17.36 \pm 1.45^{\mathrm{a}}$ \\
\hline \multicolumn{4}{|l|}{ Biochemical indices } \\
\hline$A L B[g / l]$ & $18.21 \pm 0.86^{\mathbf{a}}$ & $20.24 \pm 0.60^{\mathrm{a}}$ & $18.58 \pm 0.69^{\mathrm{a}}$ \\
\hline $\mathrm{NH}_{3}[\mu \mathrm{mol} / \mathrm{l}]$ & $240.30 \pm 16.24^{\mathrm{a}}$ & $245.17 \pm 18.09^{\mathrm{a}}$ & $262.13 \pm 21.52^{\mathrm{a}}$ \\
\hline$T P[g / l]$ & $36.37 \pm 1.32^{\mathrm{a}}$ & $39.68 \pm 0.96^{\mathbf{a}}$ & $36.41 \pm 1.06^{\mathrm{a}}$ \\
\hline GLU [mmol/l] & $4.28 \pm 0.17^{\mathrm{a}}$ & $4.89 \pm 0.20^{\mathrm{a}}$ & $4.20 \pm 0.09^{\mathrm{a}}$ \\
\hline$T G[\mathrm{mmol} / \mathrm{l}]$ & $2.54 \pm 0.31^{\mathrm{a}}$ & $4.29 \pm 0.67^{\mathrm{a}}$ & $3.62 \pm 0.51^{\mathrm{a}}$ \\
\hline CHOL [mmol/l] & $7.47 \pm 0.38^{\mathrm{a}}$ & $8.49 \pm 0.26^{\mathrm{a}}$ & $7.73 \pm 0.37^{\mathbf{a}}$ \\
\hline$L A C T[\mathrm{mmol} / \mathrm{l}]$ & $2.36 \pm 0.27^{\mathrm{a}}$ & $2.48 \pm 0.32^{\mathrm{a}}$ & $2.58 \pm 0.26^{\mathrm{a}}$ \\
\hline $\mathrm{Ca}[\mathrm{mmol} / \mathrm{l}]$ & $2.56 \pm 0.04^{\mathrm{a}}$ & $2.69 \pm 0.05^{\mathrm{a}}$ & $2.64 \pm 0.05^{\mathrm{a}}$ \\
\hline PHOS [mmol/l] & $3.93 \pm 0.10^{\mathrm{a}}$ & $3.98 \pm 0.09^{\mathrm{a}}$ & $4.07 \pm 0.09^{\mathrm{a}}$ \\
\hline$A L P[\mu \mathrm{kat} / l]$ & $1.06 \pm 0.14^{\mathrm{a}}$ & $1.52 \pm 0.17^{\mathrm{a}}$ & $1.08 \pm 0.09^{\mathrm{a}}$ \\
\hline$A L T[\mu k a t / l]$ & $0.29 \pm 0.04^{\mathrm{a}}$ & $0.23 \pm 0.02^{\mathrm{a}}$ & $0.23 \pm 0.01^{\mathrm{a}}$ \\
\hline$A S T[\mu k a t / l]$ & $6.30 \pm 0.76^{\mathrm{a}}$ & $5.80 \pm 0.44^{\mathrm{a}}$ & $6.08 \pm 0.28^{\mathrm{a}}$ \\
\hline$L D H[\mu k a t / l]$ & $12.04 \pm 1.03^{\mathrm{a}}$ & $9.88 \pm 0.78^{\mathrm{a}}$ & $12.46 \pm 1.76^{\mathrm{a}}$ \\
\hline
\end{tabular}

Data are given as mean $\pm S D ; n=20 / g r o u p$. Means in the same row lacking a common letter of superscript (a, b) differ significantly $(p<0.05)$. RBC - red blood cells count, Hb - hemoglobin concentration, PCV - hematocrit, MCV - mean erythrocyte volume, MCH mean erythrocyte hemoglobin, MCHC - mean corpuscular hemoglobin concentration, WBC - white blood cell count.

\section{Biochemical profile}

Surprisingly, there were no significant changes in any observed biochemical parameter and all the indices were at physiological levels. An overview of biochemical analysis results is presented in Table 1.

\section{VTG}

The VTG concentration was measured in plasma samples of both AHTN exposure groups in comparison with the control group. Surprisingly, even though the control group consisted of males, which should have served as a negative control, $20 \%$ samples were positive with VTG levels between 303 and $985 \mathrm{ng} / \mathrm{ml}$. With the lower concentration (AHTN1), the VTG concentration ranged between 173 and $945 \mathrm{ng} / \mathrm{ml}$ in $25 \%$ samples. However, in the higher concentration (AHTN2), positivity was detected in $15 \%$ cases with a concentration range from 362 to $609 \mathrm{ng} / \mathrm{ml}$. The results are shown in Figure 1. 


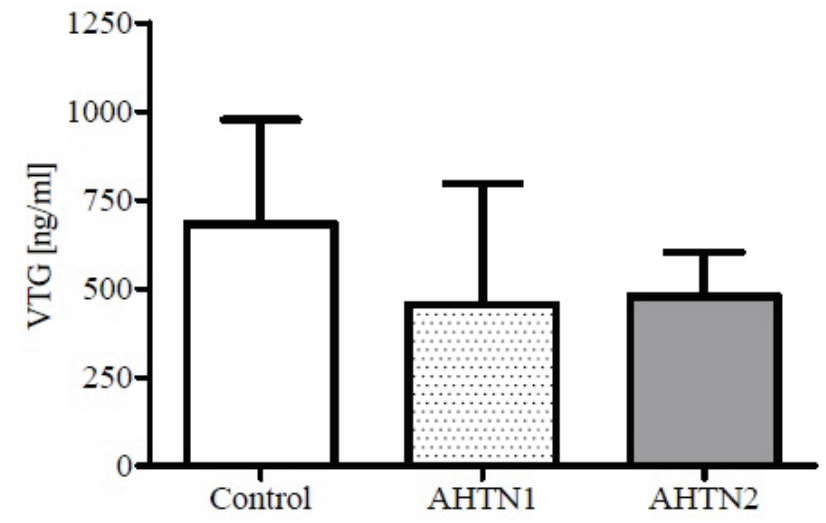

Fig. 1. The concentration of vitellogenin (VTG) in $\mathrm{ng} / \mathrm{ml}$ in plasma samples after oral exposure to two different concentrations of tonalide (AHTN): AHTN $(854 \mu \mathrm{g} / \mathrm{kg})$ and AHTN2 $(8699 \mu \mathrm{g} / \mathrm{kg})$. Data are given as mean $\pm S D ; n=20$ /group. No significant changes were found among the tested groups ( $p>0.05)$.

\section{Oxidative stress profile}

Oxidative stress was measured in both plasma and tissue samples. In the case of plasma, CP and FRAP did not show any significant changes. For tissue samples, significant changes were detected in the caudal kidney tissue where TBARS control levels significantly differed from both AHTN1 and AHTN2. In AHTN1, a decrease was observed as compared with the control, while, in contrast, a significant increase was detected for AHTN2. The results are given in Table 2.

\section{Histopathological profile}

The histopathological changes in AHTN1 and AHTN2 groups showed congestion and mixed hepatodystrophy in all liver tissues. In the control group,

Table 2. Oxidative stress parameters in plasma, liver, caudal kidney, gill and gonads after oral exposure to two different concentrations of tonalide (AHTN): AHTN1 $(854 \mu \mathrm{g} / \mathrm{kg})$ and AHTN2 $(8699 \mu \mathrm{g} / \mathrm{kg})$. Data are given as mean \pm SD; $\mathrm{n}=20 / \mathrm{group}$. Means in the same row lacking a common superscript letter $(\mathbf{a}, \mathbf{b})$ differ significantly $(p<0.05)$. CP - ceruloplasmin, FRAP - reducing ability of plasma, GR glutathione reductase, GPx - glutathione peroxidase, GST - glutathione- $S$-transferase, TBARS - thiobarbituric acid-substances.

\begin{tabular}{|c|c|c|c|}
\hline Parameter [unit] & Control & AHTN1 & AHTN2 \\
\hline \multicolumn{4}{|l|}{ Plasma } \\
\hline$C P[\Delta A / \min \times 10000]$ & $113.3 \pm 3.3^{\mathbf{a}}$ & $120.1 \pm 5.1^{\mathrm{a}}$ & $114.1 \pm 4.2^{\mathrm{a}}$ \\
\hline FRAP $[\mu \mathrm{mol} / \mathrm{l}]$ & $748.7 \pm 42.6^{\mathbf{a}}$ & $759.6 \pm 22.0^{\mathbf{a}}$ & $805.4 \pm 22.7^{\mathbf{a}}$ \\
\hline \multicolumn{4}{|l|}{ Liver } \\
\hline GR [nmol NADPH/min/mg protein] & $13.3 \pm 5.9^{\mathrm{a}}$ & $10.4 \pm 3.9^{\mathrm{a}}$ & $10.9 \pm 5.6^{\mathrm{a}}$ \\
\hline GPx [nmol NADPH/min/mg protein] & $35.1 \pm 10.1^{\mathrm{a}}$ & $37.5 \pm 10.5^{\mathrm{a}}$ & $34.7 \pm 9.0^{\mathrm{a}}$ \\
\hline GST [nmol/min/mg protein] & $683.2 \pm 184.6^{\mathbf{a}}$ & $785.4 \pm 194.8^{\mathbf{a}}$ & $681.6 \pm 178.6^{\mathbf{a}}$ \\
\hline TBARS [nmol/g of tissue] & $22.8 \pm 20.0^{\mathbf{a}}$ & $19.0 \pm 9.4^{\mathrm{a}}$ & $22.9 \pm 11.2^{\mathrm{a}}$ \\
\hline \multicolumn{4}{|l|}{ Caudal kidney } \\
\hline GR [nmol NADPH/min/mg protein] & $11.0 \pm 3.7^{\mathrm{a}}$ & $9.4 \pm 2.3^{\mathrm{a}}$ & $10.3 \pm 3.1^{\mathrm{a}}$ \\
\hline GPx [nmol NADPH/min/mg protein] & $65.6 \pm 16.8^{\mathrm{a}}$ & $58.4 \pm 14.6^{\mathrm{a}}$ & $57.2 \pm 18.2^{\mathrm{a}}$ \\
\hline GST [nmol/min/mg protein] & $393.4 \pm 206.8^{\mathbf{a}}$ & $440.2 \pm 170.9^{\mathrm{a}}$ & $411.0 \pm 242.6^{\mathrm{a}}$ \\
\hline TBARS [nmol/g of tissue] & $10.0 \pm 10.6^{\mathbf{a}, \mathbf{b}}$ & $8.4 \pm 5.0^{\mathbf{b}}$ & $12.9 \pm 7.8^{\mathbf{a}}$ \\
\hline \multicolumn{4}{|l|}{ Gill } \\
\hline GR [nmol NADPH/min/mg protein] & $13.5 \pm 4.3^{\mathrm{a}}$ & $11.8 \pm 3.6^{\mathbf{a}}$ & $11.5 \pm 2.3^{\mathrm{a}}$ \\
\hline GPx [nmol NADPH/min/mg protein] & $62.0 \pm 13.4^{\mathrm{a}}$ & $65.7 \pm 12.0^{\mathrm{a}}$ & $64.6 \pm 10.3^{\mathrm{a}}$ \\
\hline GST [nmol/min/mg protein] & $280.6 \pm 98.1^{\mathbf{a}}$ & $238.4 \pm 65.4^{\mathrm{a}}$ & $214.7 \pm 72.0^{\mathrm{a}}$ \\
\hline TBARS [nmol/g of tissue] & $20.2 \pm 7.9^{\mathrm{a}}$ & $22.7 \pm 11.7^{\mathrm{a}}$ & $24.0 \pm 15.0^{\mathrm{a}}$ \\
\hline \multicolumn{4}{|l|}{ Gonads } \\
\hline GR [nmol NADPH/min/mg protein] & $11.0 \pm 3.5^{\mathrm{a}}$ & $11.1 \pm 1.6^{\mathrm{a}}$ & $10.6 \pm 4.6^{\mathrm{a}}$ \\
\hline GPx [nmol NADPH/min/mg protein] & $30.9 \pm 12.5^{\mathrm{a}}$ & $28.7 \pm 5.0^{\mathrm{a}}$ & $28.0 \pm 7.8^{\mathrm{a}}$ \\
\hline GST [nmol/min/mg protein] & $115.3 \pm 57.0^{\mathbf{a}}$ & $93.9 \pm 27.6^{\mathrm{a}}$ & $102.4 \pm 39.0^{\mathrm{a}}$ \\
\hline
\end{tabular}




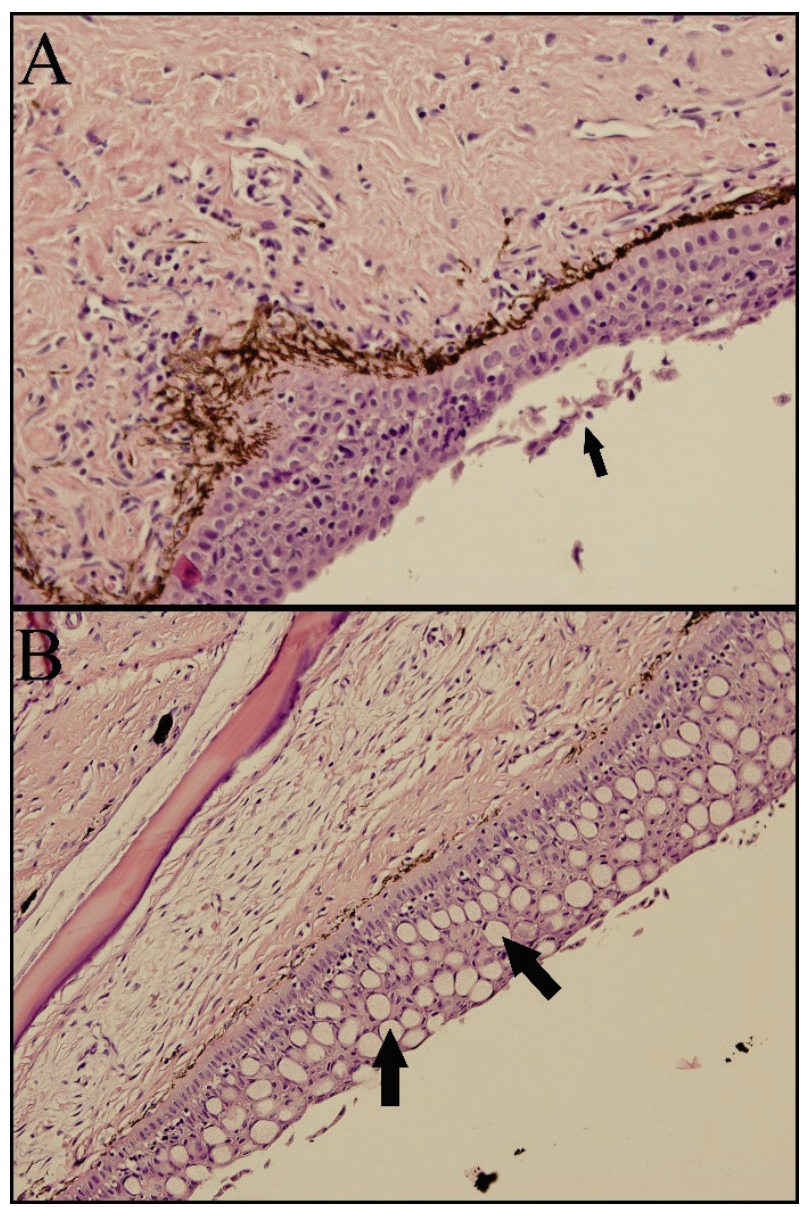

Fig. 2. The histopathological findings in skin tissue after oral exposure to two different concentrations of tonalide (AHTN): AHTN1 $(854 \mu \mathrm{g} / \mathrm{kg})$ and AHTN2 $(8699 \mu \mathrm{g} / \mathrm{kg})$. The control group (A) with artificial superficial erosion (black arrow), otherwise without pathological findings. The AHTN2 group (B) with numerous mucinous cells (black arrows). H-E staining, magnification 400X.

dystrophy was also observed together with small deposits of pigments; otherwise, the liver tissue in the control was without gross lesions. For the cranial kidney, congestion was observed along with hyaline degeneration of some tubules in AHTN1; in higher concentration, congestion was observed simultaneously with small deposits of pigments - the same finding as in the control group. In contrast, the caudal kidney showed multiple pigment deposits with intact parenchyma in AHTN1 and congestion with hyaline degeneration of some tubules in AHTN2. In the control, pigment deposits with hyaline droplets in some tubules of the caudal kidney were. The gill lamellas were hypertrophic and vacuolization together with surface alterations was observed in AHTN1. In AHTN2, total devastation of lamellas with inflammatory lesions was observed. The control group was intact. Spleen tissue in both AHTN1 and AHTN2 showed congestion with intact parenchyma; the same findings were observed in the control group. Skin tissue in the control was without gross lesions; the higher the AHTN concentration, the more mucinous cells were observed and, in AHTN2, myodystrophia was also revealed. The gonads were completely intact in the control and both experimental groups. The histopathological changes of skin tissue and caudal kidney compared to control group are presented in Figure 2 and 3, respectively.

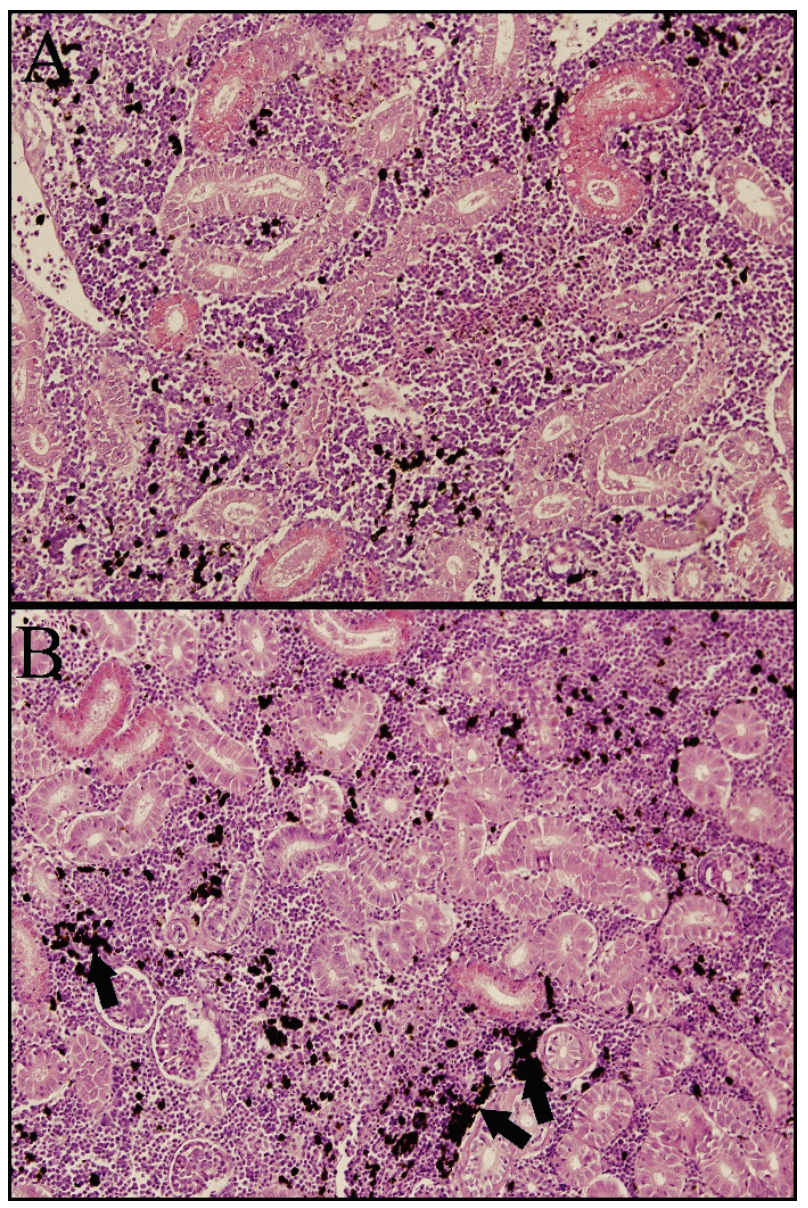

Fig. 3. The histopathological findings in caudal kidney tissue after oral exposure to two different concentrations of tonalide (AHTN): AHTN1 $(854 \mu \mathrm{g} / \mathrm{kg})$ and AHTN2 $(8699 \mu \mathrm{g} / \mathrm{kg})$. The control group (A) with normal tubular system and some pigmented deposits. The AHTN2 group (B) with droplet hyaline degeneration of some tubules (black arrows). H-E staining, magnification $200 x$.

\section{Discussion}

The presence of PCMs, and AHTN specifically, was observed in many environmental matrices, due to not $100 \%$ effective water purification and high bioaccumulation capacity and stability (Li et al. 2020). Thus, AHTN presence was detected in surface water, drinking water, sediment or even in the air and biota, as 
reviewed by Tumova et al. (2019). The aquatic biota is the main vulnerable group due to the reported adverse effects on the health of its organisms, as discussed above. As the model organism for our study, the rainbow trout was selected to be the typical fish in our country with a high bioaccumulation level and, to our knowledge, no PCMs toxicity testing has ever been performed in this organism.

According to biometrical analysis, hematological and biochemical indices, there were significant changes in PCV which increased in both AHTN1 and AHTN2. Additionally, the MCV also increased depending on AHTN concentration; in contrast, the $\mathrm{MCH}$ and MCHC were significantly decreased in both tested AHTN concentrations. These findings indicated that erythrocytes could become swollen by induction with AHTN, as it was previously documented in fish by sudden $\mathrm{pH}$ changes (Harter et al. 2018); the swelling could lead to irregularities in physiological functions of erythrocytes (Javed et al. 2016). The prolonged exposure to higher AHTN concentrations could thus be harmful for maintaining homeostasis.

The main goal of our experiment was to assess the endocrine disruption effects of AHTN, while the production of VTG served as a marker of xenoestrogenic potential. VTG is a precursor of egg yolk and is synthetized in female liver. Even though the juveniles and males also have the gene for VTG synthesis present in their genetic equipment, gene expression does not occur. However, some chemicals with endocrine-disruptive potential can induce VTG synthesis and its production and this potential were also reported for AHTN (Sumpter and Jobling 1995, Jobling et al. 1996, Yamauchi et al. 2008). In our experiment, $25 \%$ and $15 \%$ of the samples were positive for VTG in the AHTN1 and AHTN2 groups, respectively. Even though $20 \%$ of samples were positive in the control group, the concentration levels were just slightly above the detection limit. The differences in total VTG concentrations in plasma between the control and both tested AHTN groups were without statistical significance and were not higher than $1000 \mathrm{ng} / \mathrm{ml}$. In contrast, the physiological VTG detection limit is 200 to million-fold higher in females than males depending on their sexual maturity (Copeland et al. 1986, Wozny et al. 2020). The positivity in some of our negative control samples was probably caused by the fish origin as they were taken from natural water sources where chemicals with endocrine-disrupting potential could be present. In summary, due to the detected VTG levels in male samples, endocrine disruption caused by AHTN was not confirmed for rainbow trout.

The induction of oxidative stress in tissues after AHTN exposure was previously reported in earthworm (Chen et al. 2011), zebra mussel (Parolini et al. 2015), shrimp larvae (Li et al. 2020) and zebrafish (Blahova et al. 2018). The multiplication of free radicals could lead to cellular or tissue damage because they are not completely disposed by antioxidant enzymes. In our study, the oxidative stress marker TBARS was significantly increased in caudal kidney tissue in AHTN2. The TBARS is a marker of lipid peroxidation and its analysis includes not only detection of the major formed substance, malondialdehyde (MDA), but also the minor related compounds developing in response to oxidative stress (Wang et al. 2014, Chen et al. 2012). When the goldfish Carassius auratus (Linnaeus 1758) was exposed to another PCM representative, $\mathrm{HHCB}$, the activity of antioxidant enzymes (superoxide dismutase, catalase and peroxidase) was significantly elevated with a correlation to higher tested HHCB concentrations. Additionally, MDA in fish liver also increased. In the same study, the prolonged HHCB exposure led to modulation of antioxidant defense system and the enzyme levels returned to their initial levels after 21 days. Similarly, increased levels of superoxide dismutase, catalase, GST and MDA were observed in shrimp larvae after their exposure to AHTN by Li et al. (2020). In our study, the environmentally-relevant AHTN1 concentration was probably tolerable for fish with the origin in free nature and the antioxidant capacity was able to maintain a balance. However, with a 10-times higher concentration, the TBARS content significantly increased, thus confirming the disruption of the cell antioxidant defense system in caudal kidney.

The histopathological findings on the caudal kidney in AHTN2 revealed congestion and hyaline degeneration of some tubules (Fig. 3) which could have developed as a response to AHTN and formed reactive oxygen species causing oxidative stress in cells. Additionally, some pathological findings were discovered in the liver and skin histological images. The hepatic dystrophy in liver tissue is a response to toxic effects of AHTN, as previously reported in the case of other PCMs including AHTN for Chinese sturgeon Acipenser sinensis (Wan et al. 2007), medaka Oryzias latipes (Yamauchi et al. 2008) and goldfish C. auratus (Chen et al. 2012). In 
the case of skin, hyperplasia of mucinous cells was found. These cells are responsible for production of the mucous layer on the fish body surface serving as the innate immune barrier (Dash et al. 2018). Multiplication of these cells is a response to disruption of the physiological barrier, which could, if severe, lead to a lower ability to defend the body against pathogens, while fish mucus includes many bactericidal substances for fish protection. Together with the observed hepatic dystrophy, the presence of AHTN in surface water could be potentially harmful to the fish organism and maintaining homeostasis.

Based on the data collected in this study, the presence of AHTN in surface waters can lead to disruptions in physiological parameters and have a potential to cause tissue damage and metabolic disorders as a result of lipid peroxidation in rainbow trout. However, no effect on mortality, behaviour, biochemical profile and endocrine disruption was observed in our experiment.

\section{Conclusions}

In conclusion, the result of our experiment showed that the musk compound AHTN has no effect on mortality, behaviour and hematological or biochemical indices, except for PCV, which increased after exposure to both tested concentrations. Formation of reactive oxygen species was not found in plasma samples, based on CP and FRAP results. However, the induction of lipid peroxidation was confirmed in caudal kidney. The xenoestrogenic potential of AHTN was not confirmed.

\section{Conflict of Interest}

There is no conflict of interest.

\section{Acknowledgements}

Project was funded by the ERDF/ESF "PROFISH" [no. CZ.02.1.01/0.0/0.0/16_019/0000869]. Authors would like to thank Mrs. Ludmila Faldikova for manuscript improvement and English correction.

\section{References}

APHA: Standard Methods for the Examination of Water and Wastewater, 23rd. BAIRD RB, EATON AD, RICE EW (eds), American Public Health Association, American Water Works Association and Water Environment Federation, Washington D.C., 2017, 1504 p.

BENZIE IFF, STRAIN JJ: The ferric reducing ability of plasma (FRAP) as a measure of "antioxidant power": The FRAP assay. Anal Biochem 239: 70-76, 1996. https://doi.org/10.1006/abio.1996.0292

BLAHOVA J, DIVISOVA L, PLHALOVA L, ENEVOVA V, HOSTOVSKY M, DOUBKOVA V, MARSALEK P, FICTUM P, SVOBODOVA Z: Multibiomarker responses of juvenile stages of zebrafish (Danio rerio) to subchronic exposure to polycyclic muck tonalide. Arch Environ Con Tox 74: 568-576, 2018. https://doi.org/10.1007/s00244-017-0484-8

CARLBERG I, MANNERVIK B: Purification and characterization of the flavoenzyme glutathione reductase from rat liver. J Biol Chem 250: 5475-5480, 1975.

CARLSSON G, PATRING J, KREUGER J, NORRGREN L, OSKARSSON A: Toxicity of 15 veterinary pharmaceuticals in zebrafish (Danio rerio) embryos. Aquat Toxicol 126: 30-41, 2013. https://doi.org/10.1016/j.aquatox.2012.10.008

CARLSSON G, NORRGREN L: Comparison of embryo toxicity using two classes of aquatic vertebrates. Environ Toxicol Pharmacol 37: 24-27, 2014. https://doi.org/10.1016/j.etap.2013.10.015

CERON JJ, MARTINEZ-SUBIELA S: An automated spectrophotometric method for measuring canine ceruroplasmin in serum. Vet Res 35: 671-679, 2004. https://doi.org/10.1051/vetres:2004046

CHEN C, ZHOU Q, LIU S, XIU Z: Acute toxicity, biochemical and gene expression responses of the earthworm Eisenia fetida exposed to polycyclic musks. Chemosphere 83: 1147-1154, 2011. https://doi.org/10.1016/j.chemosphere.2011.01.006

CHEN D, ZENG X, SHENG Y, BI X, GUI H, SHENG G, FU J: The concentrations and distribution of polycyclic musks in a typical cosmetic plant. Chemosphere 66: 252-258, 2007. https://doi.org/10.1016/j.chemosphere.2006.05.024 
CHEN F, GAO J, ZHOU QX: Toxicity assessment of simulated urban runoff containing polycyclic musks and cadmium in Carassius auratus using oxidative stress biomarkers. Environ Pollut 162: 91-97, 2012. https://doi.org/10.1016/j.envpol.2011.10.016

COPELAND PA, SUMPTER JP, WALKER TK, CROFT M: Vitellogenin levels in male and female rainbow trout (Salmo gairdneri Richardson) at various stages of the reproductive cycle. Comp Biochem Phys B 83: 487-493, 1986. https://doi.org/10.1016/0305-0491(86)90400-1

DASH S, DAS SK, SAMAL J, THATOI HN: Epidermal mucus, a major determinant in fish health: a review. Iran J Vet Res 19: 72-81, 2018.

EUROPEAN COMMISSION: Regulation (EC) No 1223/2009 of the European Parliament and of the Council of 30 November 2009 on cosmetic products. In: Official Journal of the European Union. Available at: https://eurlex.europa.eu/legal-content/EN/TXT/PDF/?uri=CELEX:32009R1223 \&from=EN [2019-08-23], 151 pp, 2009.

FANG H, GAO Y, WANG H, YIN H, LI G, AN T: Photoinduced oxidative damage to dissolved free amino acids by the photosensitizer polycyclic musk tonalide: Transformation kinetics and mechanisms. Water Res 115: 339-346, 2017. https://doi.org/10.1016/j.watres.2017.03.006

FLOHE L, GUNZLER WA: Assays of glutathione peroxidase. Methods Enzymol 105: 114-121, 1984. https://doi.org/10.1016/S0076-6879(84)05015-1

FREITAS R, SILVESTRO S, COPPOLA F, MEUCCI V, BATTAGLIA F, INTORRE L, SOARES AMVM, PRETTI C, FAGGIO C: Biochemical and physiological responses induced in Mytilus galloprovincialis after a chronic exposure to salicylic acid. Aquat Toxicol 214: 105258, 2019. https://doi.org/10.1016/j.aquatox.2019.105258

FROESE R: Cube law, condition factor and weight-length relationships: history, meta-analysis and recommendations. J Appl Ichthyol 22: 241-253, 2006. https://doi.org/10.1111/j.1439-0426.2006.00805.x

FROMME H, OTTO T, PILZ K: Polycyclic musk fragrances in different environmental compartments in Berlin (Germany). Water Res 35: 121-128, 2001. https://doi.org/10.1016/S0043-1354(00)00233-5

HABIG WH, PABST MJ, JAKOBY WB: Glutathione S-transferases. The first enzymatic step in mercapturic acid formation. J Biol Chem 249: 7130-7139, 1974.

HARTER TS, MAY AG, FEDERSPIEL WJ, SUPURAN CT, BRAUNER CJ: Time course of red blood cell intracellular pH recovery following short-circuiting in relation to venous transit times in rainbow trout, Oncorhynchus mykiss. Am J Physiol Regul Integr Comp Physiol 315: 397-407, 2018. https://doi.org/10.1152/ajpregu.00062.2018

HEBERER T: Occurrence, fate, and assessment of polycyclic musk residues in the aquatic environment of urban areas a review. Acta Hydrochim Hydrobiol 30: 227-243, 2002. https://doi.org/10.1002/aheh.200390005

HOMEM V, SILVA JA, RATOLA N, SANTOS L, ALVES A: Long lasting perfume - A review of synthetic musks in WWTPs. J Environ Manag 149: 168-192, 2015. https://doi.org/10.1016/j.jenvman.2014.10.008

JAVED M, AHMAD I, AHMAD A, USMANI N, AHMAD M: Studies on the alterations in haematological indices, micronuclei induction and pathological marker enzyme activities in Channa punctatus (spotted snakehead) perciformes, channidae exposed to thermal power plant effluent. SpringerPlus 5: 761, 2016. https://doi.org/10.1186/s40064-016-2478-9

JOBLING S, SHEAHAN D, OSBORNE JA, MATTHIESSEN P, SUMPTER JP: Inhibition of testicular growth in rainbow trout (Oncorhynchus mykiss) exposed to estrogenic alkylphenolic chemicals. Environ Toxicol Chem 15: 194-202, 1996. https://doi.org/10.1002/etc.5620150218

KANNAN K, REINER JL, YUN SH, PERROTTA EE, TAO L, JOHNSONRESTREPO B, RODAN BD: Polycyclic musk compounds in higher trophic level aquatic organisms and humans from the United States. Chemosphere 61: 693-700, 2005. https://doi.org/10.1016/j.chemosphere.2005.03.041

LANGE C, KUCH B, METZGER JW: Occurrence and fate of synthetic musk fragrances in a small German river. J Hazard Mater 282: 34-40, 2015. https://doi.org/10.1016/j.jhazmat.2014.06.027

LI W, WANG S, LI J, WANG X, CUI L, CHEN J, LIU Z: Antioxidative enzyme activities in the Rhodeinae sinensis Gunther and Macrobrachium nipponense and multi-endpoint assessment under tonalide exposure. Ecotox Environ Safe 199: 110751, 2020. https://doi.org/10.1016/j.ecoenv.2020.110751

LUCKENBACH T, EPEL D: Nitromusk and polycyclic musk compounds as long-term inhibitors of cellular xenobiotic defense systems mediated by multidrug transporters. Environ Health Perspect 113: 17-24, 2005. https://doi.org/10.1289/ehp.7301 
LUSHCHAK VI, BAGNYUKOVA TV, LUSHCHAK OV, STOREY JM, STOREY KB: Hypoxia and recovery perturb free radical processes and antioxidant potential in common carp (Cyprinus carpio) tissues. Int J Biochem Cell Biol 37: 1319-1330, 2005. https://doi.org/10.1016/j.biocel.2005.01.006

MAZLAN AG, ROHAYA M: Size, growth and reproductive biology of the giant mudskipper, Periophthalmodon schlosseri (Pallas, 1770), in Malaysian waters. J Appl Ichthyol 24: 290-296, 2008. https://doi.org/10.1111/j.1439-0426.2007.01033.x

MODRA H, PALIKOVA M, HYRSL P, BARTONKOVA J, PAPEZIKOVA I, SVOBODOVA Z, BLAHOVA J, MARES $\mathrm{J}$ : Effects of trichothecene mycotoxin T-2 toxin on haematological and immunological parameters of rainbow trout (Oncorhynchus mykiss). Mycotoxin Res 36: 319-326, 2020. https://doi.org/10.1007/s12550-020-00396-7

NAKATA H, HINOSAKA M, YANAGIMOTO H: Macrocyclic-, polycyclic-, and nitromusks in cosmetics, household commodities and indoor dusts collected from Japan: implications for their human exposure. Ecotoxicol Environ Saf 111: 248-255, 2015. https://doi.org/10.1016/j.ecoenv.2014.09.032

PABLOS MV, JIMÉNEZ MÁ, SEGUNDO LS, MARTINI F, BELTRÁN E, FERNÁNDEZ C: Effects of dietary exposure of polycyclic musk HHCB on the metamorphosis of Xenopus laevis. Environ Toxicol Chem 35: 1428-1435, 2015. https://doi.org/10.1002/etc.3286

PAROLINI M, MAGNI S, TRAVERSI I, VILLA S, FINIZIO A, BINELLI A: Environmentally relevant concentrations of galaxolide (HHCB) and tonalide (AHTN) induced oxidative and genetic damage in Dreissena polymorpha. J Hazard Mater 285: 1-10, 2015. https://doi.org/10.1016/j.jhazmat.2014.11.037

PECK A, HORNBUCKLE K: Synthetic musk fragrances in Lake Michigan. Environ Sci Technol 38: 367-382, 2004. https://doi.org/10.1021/es034769y

RAMIERZ A, BRAIN R, USENKO S, MOTTALEB M, O'DONNELL JG, STAHL LL, WATHEN JB, SNYDER BD, PITT, JL, PEREZ-HURTADO P, DOBBINS LL, BROOKS BW, CHAMBLISS CK: Occurrence of pharmaceuticals and personal care products in fish: Results of a national pilot study in the United States. Environ Toxicol Chem 28: 2587-2597, 2009. https://doi.org/10.1897/08-561.1

REN Y, WEI K, LIU H, SUI G, WANG J, SUN Y, ZHENG X: Occurrence and removal of selected polycyclic musks in two sewage treatment plants in Xi'an, China. Front Env Sci Eng 7: 166-172, 2013. https://doi.org/10.1007/s11783-012-0471-2

RIMKUS GG: Polycyclic musk fragrances in the aquatic environment. Toxicol Lett 111: 37-56, 1999. https://doi.org/10.1016/S0378-4274(99)00191-5

SCHREURS RHMM, LEGLER J, ARTOLA-GARICANO E, SINNIGE TL, LANSER PH, SEINER W, VAN DER BURG B: In vitro and in vivo antiestrogenic effects of polycyclic musks in zebrafish. Environ Sci Technol 38: 997-1002, 2004. https://doi.org/10.1021/es034648y

SEHONOVA P, HODKOVICOVA N, URBANOVA M, ORN S, BLAHOVA J, SVOBODOVA Z, FALDYNA M, CHLOUPEK P, BRIEDIKOVA K, CARLSSON G: Effects of antidepressants with different modes of action on early life stages of fish and amphibians. Environ Pollut 254: 112999, 2019. https://doi.org/10.1016/j.envpol.2019.112999

SHI J, LI M, JIAO Z, ZHANG J, FENG Y, SHAO B: Microarray analysis of gene expression in mouse (Strain 129) embryonic stem cells after typical synthetic musk exposure. Bull Environ Contam Toxicol 90: 17-21, 2013. https://doi.org/10.1007/s00128-012-0865-7

SIMMONS DBD, MARLATT VL, TRUDEAU VL, SHERRY JP, METCALFE CD: Interaction of Galaxolide ${ }^{\circledR}$ with the human and trout estrogen receptor- $\alpha$. Sci Total Environ 408: 6158-6164, 2010. https://doi.org/10.1016/j.scitotenv.2010.09.027

SMITH PK, KROHN RI, HERMANSON GT, MALLIA AK, GARTNER FH, PROVENZANO MD, FUJIMOTO EK, GOEKE NM, OLSON BJ, KLENK DC: Measurement of protein using bicinchoninic acid. Anal Biochem 150: 76-85, 1985. https://doi.org/10.1016/0003-2697(85)90442-7.

SUMPTER JP, JOBLING S: Vitellogenesis as a biomarker for estrogenic contamination of the aquatic environment. Environmen Health Perspect 103: 173-178, 1995. https://doi.org/10.1289/ehp.95103s 7173

SVOBODOVA Z, PRAVDA D, MODRA H: Unified Methods of Haematological Examination of Fish. University of South Bohemia in Ceske Budejovice, Czech Republic, 2012, 38 p. 
TUMOVA J, SAUER P, GOLOVKO O, UCUN OK, GRABIC R, MACHOVA J, KOCOUR KROUPOVA H: Effect of polycyclic musk compounds on aquatic organisms: A critical literature review supplemented by own data. Sci Total Environ 651: 2235-2246, 2019. https://doi.org/10.1016/j.scitotenv.2018.10.028

VALLECILLOS L, BORRULL F, POCURULL E: Recent approaches for the determination of synthetic musk fragrances in environmental samples. Trend Anal Chem 72: 80-92, 2015. https://doi.org/10.1016/j.trac.2015.03.022

WAN Y, WEI Q, HU J, JIN X, ZHANG Z, ZHEN H, LIU J: Levels, tissue distribution, and age-related accumulation of synthetic musk fragrances in Chinese sturgeon (Acipenser sinensis): comparison to organochlorines. Environ Sci Technol 41: 424-430, 2007. https://doi.org/10.1021/es061771r

WANG XN, LIU ZT, WANG WH, YAN ZG, ZHANG C, WANG WL, CHEN LH: Assessment of toxic effects of triclosan on the terrestrial snail (Achatina fulica). Chemosphere 108: 225-230, 2014. https://doi.org/10.1016/j.chemosphere.2014.01.044

WOMBACHER W, HORNBUCKLE K: Synthetic musk fragrances in a conventional drinking water treatment plant with lime softening. J Environ Eng 135: 1192, 2009. https://doi.org/10.1061/(ASCE)EE.1943-7870.0000085

WONG F, ROBSON M, MELYMUK L, SHUNTHIRASINGHAM C, ALEXANDROU N, SHOEIB M, LUK E, HELM P, DIAMOND M, HUNG H: Urban sources of synthetic musk compounds to the environment. Environ Sci Process Impacts 21: 74-88, 2019. https://doi.org/10.1039/C8EM00341F

WOZNY M, DOBOSZ S, HLIWA P, GOMUŁKA P, KRÓL J, OBREMSKI K, BLAHOVA J, SVOBODOVA Z, MICHALIK O, OCALEWICZ K, BRZUZAN P: Feed-borne exposure to zearalenone impairs reproduction of rainbow trout. Aquaculture 528: 735522, 2020. https://doi.org/10.1016/j.aquaculture.2020.735522

YAMAUCHI R, ISHIBASHI H, HIRANO M, MORI T, KIM JW, ARIZONO K: Effects of synthetic polycyclic musks on estrogen receptor, vitellogenin, pregnane $\mathrm{X}$ receptor, and cytochrome $\mathrm{P} 450$ 3A gene expression in the liver of male medaka (Oryzias latipes). Aquat Toxicol 90: 261-268, 2008. https://doi.org/10.1016/j.aquatox.2008.09.007

YAO L, ZHAO JL, LIU YS, ZHANG QQ, JIANG YX, LIU S, LIU WR, YANG YY, YING GG: Personal care products in wild fish in two main Chinese rivers: Bioaccumulation potential and human health risks. Sci Total Environ 621: 1093-1102, 2018. https://doi.org/10.1016/j.scitotenv.2017.10.117

ZENG X, SHENG G, XIONG Y, FU J: Determination of polycyclic musks in sewage sludge from Guangong, China using GC-EI-MS. Chemosphere 60: 817-823, 2005. https://doi.org/10.1016/i.chemosphere.2005.04.026

ZHANG H, BU Q, WU D, YU G: Polycyclic musks in surface water and sediments from an urban catchment in the megacity Beijing, China. Environ Pollut 263: 114548, 2020. https://doi.org/10.1016/j.envpol.2020.114548 